\title{
Calculation of financial intermediation services indirectly measured (FISIM) for Islamic banking activity in Malaysia ${ }^{1}$
}

\author{
Khairul Aidah Samah*, Mohd Yazid Kasim and Mohd Fahmi Mohd Arupin \\ National Accounts Statistics Division, Department of Statistics, Malaysia
}

\begin{abstract}
The Financial intermediation services indirectly measured (FISIM) is a concept used in national accounts to value the activity of banks as intermediaries between depositors and borrowers and widely used in conventional banking. Unlike conventional banking, Islamic banking declared their loans as financing in financial position statement. While interest expense and interest received declared as "profit distributed to depositors" and "income derived from investment". The terms were compliant by the shariah law in Malaysia and this paper show on how the calculation of FISIM for Islamic banking in the context of the 2008 System of National Accounts. The calculation process is similar to conventional banks methodology, but the difference was only terms of financing instead of loans that have been used in Islamic Banking.
\end{abstract}

Keywords: Islamic banks, FISIM, System of National Accounts, reference rate

\section{Introduction}

The global Islamic Financial services industry amounted to USD2.19 trillion (IFSB report, 2019), of which the global Islamic banking industry contributed $71.7 \%$ in terms of assets valued at USD1.57 trillion (2Q2017: USD1.56 trillion) in first half 2018. Based on Islamic Financial Services Industry: Stability report 2019 (IFSB), Malaysia Islamic banking has improved its market share and ranked sixth in global market share with the contribution of $26.5 \%$ (2Q2017: $24.9 \%$ ) which was above Qatar, 25.2\% (2Q17: 25.7\%) and below Kuwait, $40.6 \%$ (2Q17: 39.3\%) [1]. Islamic banks in Malaysia are experiencing tremendous growth, with the average annual growth rate of $14.0 \%$ per annum for the

\footnotetext{
${ }^{1}$ The views expressed in this paper are the author's personal and do not necessarily reflect the views of the organizations to which they are affiliated.

${ }^{*}$ Corresponding author: Khairul Aidah Samah, National Accounts Statistics Division, Department of Statistics, Level 3, Unit 0105, Wisma Minlon, $12^{\text {th }}$ Miles, Sungai Besi Highway, 43300 Seri Kembangan, Selangor Darul Ehsan, Malaysia. E-mail: aidah.samah @ dosm.gov.my.
}

Table 1 Average annual growth of bank assets

\begin{tabular}{lc}
\hline Banking system & CAGR $(\%)$ \\
\cline { 2 - 2 } & $\begin{array}{c}\text { 2010-2019 } \\
\text { 10 years }\end{array}$ \\
\hline Commercial banks & 5.9 \\
Islamic banks & 14.0 \\
Investment banks & -2.6 \\
Total & $\mathbf{7 . 4}$ \\
\hline
\end{tabular}

Source: Bank Negara Malaysia.

past ten years (2010-2019) see Table 1. The Islamic banking industry in Malaysia has advanced significantly over the years. In terms of bank assets, Islamic banks accounted for $7.8 \%$ (RM92.3 billion) to the total banking system in 2007 and increased to a double-digit share of $28.9 \%$ (RM818.3 billion) in 2019.

As shown in Fig. 1, Malaysia's financial system comprises a diversified range of institutions that serve the needs of the domestic economy. Malaysia's Islamic finance industry has been in existence since 1969 with the establishment of the Pilgrims Management Fund and Board of Malaysia. Then the enactment of the Islamic Banking Act 1983 enabled the country's first Islamic bank to be established, and thereafter, with the liber- 


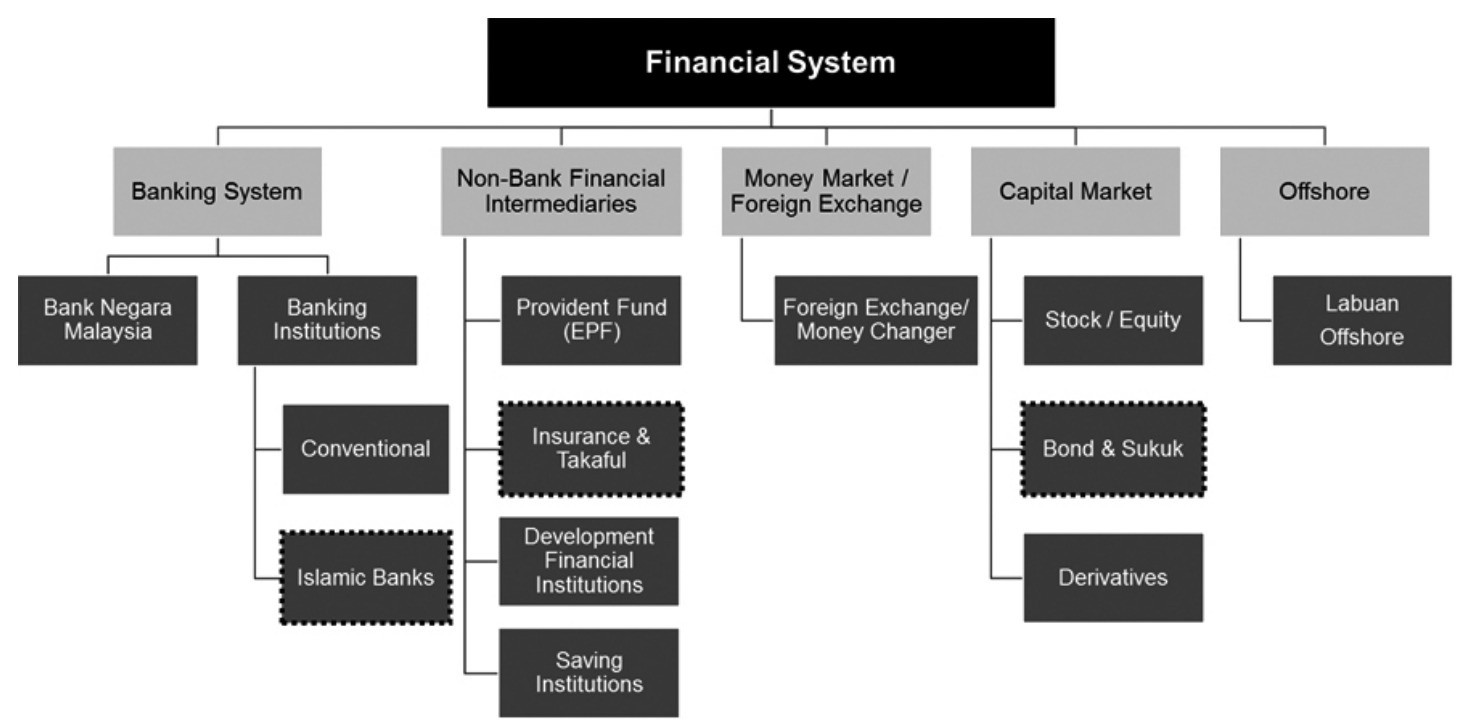

Fig. 1. Malaysia financial system and structure. Source: Bank Negara Malaysia. Note: Dash boxes indicated cover under Islamic Finance.

alization of the Islamic financial system, more Islamic financial institutions have been established. Rapid liberalization of the Islamic finance industry, and a conducive business environment have encouraged foreign financial institutions to choose Malaysia to conduct Islamic banking business. This situation has created a diverse and growing community of local and international financial institutions. With the development of Islamic finance Bank Negara-Central Bank of Malaysia had introduced Islamic Financial Services Act 2013, where an institution shall at all times ensure that its aims and operations, business, affairs, and activities comply with Shariah.

The act has enabled Bank Negara Malaysia to manage Islamic finance statistics, which subsequently used as input data in Malaysia's compilation of Gross Domestic Products (GDP). Statistics specifically for Islamic banking, has served well in the System of National Accounts framework. Hence, Department of Statistics Malaysia has taken an effort to ensure Islamic Finance statistics is covered in Malaysia's economy activity by creating code for this industry in Malaysia Standard Industrial Classification (MSIC) code. Besides, the department has incorporated the SNA framework in terms of compilation to ensure comprehensive coverage for all productive activity in Malaysia's economy.

Therefore, the objective of this paper is to share Malaysia's experience in the calculation of FISIM for Islamic banking in the context of the 2008 System of National Accounts. The calculation process was similar to conventional bank's methodology. The only differ- ence was the term financing, instead of loans used in Islamic Banking. The banking system, which fell under the supervision of Bank Negara Malaysia, consists of commercial banks, Islamic banks and investment banks, which is the primary source of financing that supports economic activities in Malaysia. Thus, this paper will limit its examination of financial intermediaries (banking institutions) to commercial banks and Islamic banks only.

\section{Islamic banking concepts and practices in Malaysia}

Economics in Islamic concept, the venture between lender and borrower should bear the risk together. Thus, a unique feature that differentiates Islamic banking from conventional banking, in theory, is its profit-and-loss sharing (PLS) paradigm. Under the PLS paradigm, the ex-ante fixed rate of return in financial contracting, which is prohibited, is replaced with a rate of return that is uncertain and determined ex-post on a profit-sharing basis. Only the profit-sharing ratio between the capital provider and the entrepreneur is determined ex-ante. PLS contracts, in general, allow two or more parties to pool their resources for investment purposes and to share the investment's profit-and-loss [2].

Most theoretical models of Islamic banking are based on the mudarabah (profit-sharing) and/or musyarakah (joint venture) concepts of PLS [3]. Therefore, it was difficult to classify Islamic financial instruments into loans or deposits into the SNA framework as the Shariah 


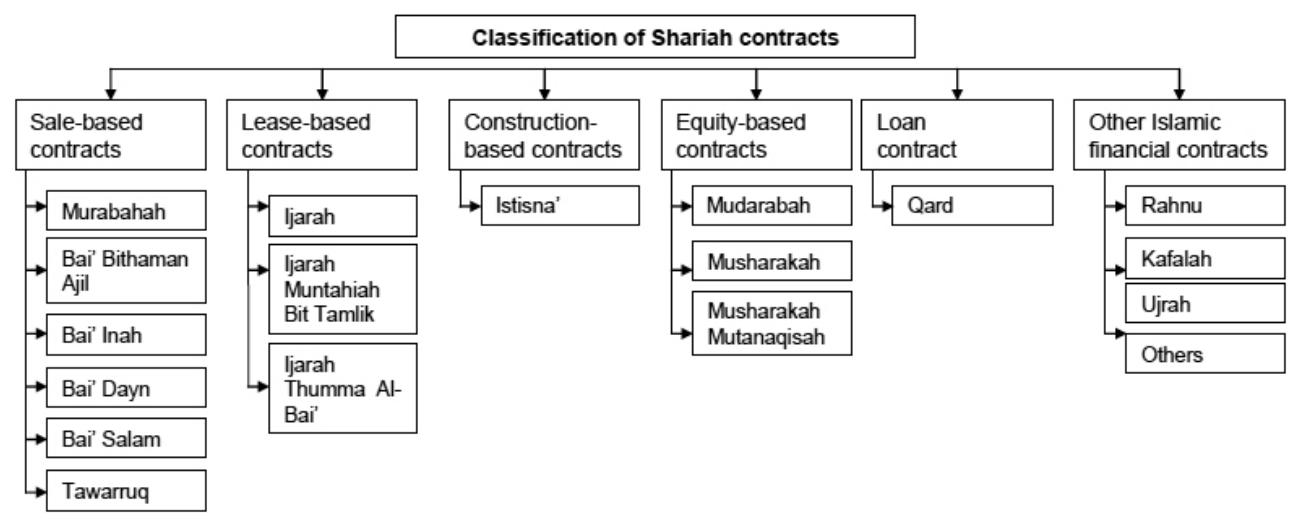

Fig. 2. Classification of shariah contracts in Malaysia. Source: Financial Reporting for Islamic Banking Institutions, Bank Negara Malaysia.

contract applies across all segments. For example, A tawarruq contract consists of two sale and purchase contracts. The first involves the sale of an asset by a seller to purchaser on a deferred basis. Subsequently, the purchase of the first sale will sell the same asset to a third party on a cash and spot basis. So that the Tawarruq contract can be used as sources of fund (term deposit) or use of fund (sales-based contract). For the classification of Shariah contracts in Malaysia, please refer to Fig. 2.

In Malaysia, there are two types of rates; the Base Lending Rate for the conventional financial institution and Base Financing Rate (BFR) for the Islamic Financial Institution, which is Shariah-compliant. Both rates determined by the Base rate, which is the benchmark cost of funds and the Statutory Reserve Requirement (SRR). BFR was the rate of return for Islamic banking and the framework has introduced by Bank Negara Malaysia (BNM). The Framework for the rate of return was aimed to standardise the methodology on the calculation of distributable profits and the derivation of the rates of return to depositors in Islamic banks. Before the introduction of the framework, the Islamic Banking industry (IBI) has adopted various methods in deriving the rates of return. Such practice has led to large variations in the results and implications. The standardization of the rates of return was also aimed at addressing the information asymmetry between the IBIs and the depositors by enhancing the level of transparency and ensuring that depositors would receive fair returns on their investment [4]. The framework would detail the items, for example, the income and expense items that need to be reported and incorporated for the calculation. The calculation table lists the items for the depositors and the bank consumptions and items that are to be solely borne by the bank.

\section{Review concept of FISIM}

According to the 2008 SNA, there are three types of financial activities; financial intermediation, the services of financial auxiliaries and other financial services. These three types of financial activities provide financial services may be paid for explicitly or implicitly. Four main ways in which financial services are provided and charged for as follows:

(i) Provided in return for explicit charges (e.g., Fee income);

(ii) Provided in association with interest charges on loans and deposits (FISIM);

(iii) Associated with the acquisition and disposal of financial assets and liabilities in financial markets;

(iv) Associated with insurance and pension schemes;

This paper will focus on the calculation process for (ii) whereby a financial institution such as a bank accepts deposits from depositors wishing to receive interest and lend the fund to borrowers whose funds are insufficient to meet their needs. The bank thus provides a mechanism to allow depositors to lend to borrowers. Each of the two parties pays a fee to the bank for the service provided. The depositors lending funds by accepting a rate of interest lower than that paid by the borrowers. The borrowers pay a fee by accepting a rate of interest higher than that paid to the lender. Thus, the bank implicitly charges the depositors and the borrower with the margin between the interest rates. From this basic idea, the concept emerges of a "reference rate" of interest. The difference between the rate paid to banks by borrowers and the reference rate plus the difference between the reference rate and actually paid to depositors as seen in Eq. (1) below. The difference was margin for the banks, which represents charges for financial intermediation services indirectly measured (FISIM). 
Table 2

The calculation process of FISIM for Islamic banking

\begin{tabular}{llll}
\hline Step & \multicolumn{1}{c}{ Type of account statement } & \multicolumn{1}{c}{ Item } & \multicolumn{1}{c}{ Formula } \\
\hline 1 & Assets, Liabilities and Equities Statements & Financing and Advances & $\mathrm{y}_{\mathrm{L}}$ \\
2 & Income and Expenditure Statement & Finance Income & $\mathrm{a}$ \\
3 & Derive & Notional Financing Rate & $\mathrm{r}_{\mathrm{L}}=\mathrm{y}_{\mathrm{L}} / \mathrm{a}$ \\
4 & Assets, Liabilities and Equities Statements & Deposits Accepted & $\mathrm{y}_{\mathrm{D}}$ \\
5 & Income and Expenditure Statement & Finance Income and hibah & $\mathrm{b}$ \\
6 & Derive & Notional Deposits Rate & $\mathrm{r}_{\mathrm{D}}=\mathrm{y}_{\mathrm{D}} / \mathrm{b}$ \\
7 & Derive & Reference Rate & $\mathrm{rr}=\left(\mathrm{r}_{\mathrm{L}}+\mathrm{r}_{\mathrm{D}}\right) / 2$ \\
8 & Derive & Finance rate spread & $\mathrm{r}_{\mathrm{L}}-\mathrm{rr} @ \mathrm{rr}_{\mathrm{D}}$ \\
9 & Derive & FISIM on Finance & $\left(\mathrm{r}_{\mathrm{L}}-\mathrm{rr}\right)^{*} \mathrm{y}_{\mathrm{L}}$ \\
10 & Derive & FISIM on Deposits & $\left(\mathrm{rr}-\mathrm{r}_{\mathrm{D}}\right)^{*} \mathrm{y}_{\mathrm{D}}$ \\
11 & Derive & Total FISIM & $(9)+(10)$ \\
\hline
\end{tabular}

Table 3

The calculation process of FISIM for commercial banking

\begin{tabular}{llll}
\hline Step & \multicolumn{1}{c}{ Type of account statement } & \multicolumn{1}{c}{ Item } & \multicolumn{1}{c}{ Formula } \\
\hline 1 & Assets, Liabilities and Equities Statements & Loans & $\mathrm{y}_{\mathrm{L}}$ \\
2 & Income and Expenditure Statement & Interest Received from Loans & $\mathrm{a}$ \\
3 & Derive & Notional Lending Rate & $\mathrm{r}_{\mathrm{L}}=\mathrm{y}_{\mathrm{L}} / \mathrm{a}$ \\
4 & Assets, Liabilities and Equities Statements & Deposits & $\mathrm{y}$ D \\
5 & Income and Expenditure Statement & Interest Expense on Deposits & $\mathrm{b}$ \\
6 & Derive & Notional Deposits Rate & $\mathrm{r}_{\mathrm{D}}=\mathrm{y}_{\mathrm{D}} / \mathrm{b}$ \\
7 & Derive & Reference Rate & $\mathrm{rr}=\left(\mathrm{r}_{\mathrm{L}}+\mathrm{r}_{\mathrm{D}}\right) / 2$ \\
8 & Derive & Interest rate spread & $\mathrm{r}_{\mathrm{L}-\mathrm{rr} @ \mathrm{rr}_{\mathrm{D}}}$ \\
9 & Derive & FISIM on Loans & $\left(\mathrm{r}_{\mathrm{L}}-\mathrm{rr}\right)^{*} \mathrm{y}_{\mathrm{L}}$ \\
10 & Derive & FISIM on Deposits & $\left(\mathrm{rr}_{\mathrm{D}} \mathrm{r}_{\mathrm{D}} \mathrm{y}_{\mathrm{D}}\right.$ \\
11 & Derive & Total FISIM & $(9)+(10)$ \\
\hline
\end{tabular}

2008 SNA para 6.166 stated the reference rate or called SNA interest is the rate between the bank interest rate between deposits and loans [5]. The reference rate should contain no service element and reflect the risk and maturity structure of deposits and loans. FISIM is a concept used in national accounts to value the activity of banks as intermediaries between depositors and borrowers. The FISIM charge is the premium earned by banks when they borrow at a wholesale rate (risk-free or reference rate) from other banks or financial institutions, and then lend to, or take deposits from consumers and business. Along with direct fees and commissions, FISIM charges are used by the bank to cover their costs and profit return. Banks earn FISIM charges on loans and deposits, from personal customers and businesses, in Malaysia and abroad.

\section{Calculation of FISIM for Islamic banking}

Unlike conventional banking, Islamic banking lends money to borrowers as financing based on Shariah contracts. Subsequently, investment returns or returns gain by the banks called "profit distributed to depositors" or "income derived from investment". The terms have already compliance by the shariah law. Hence, the out-

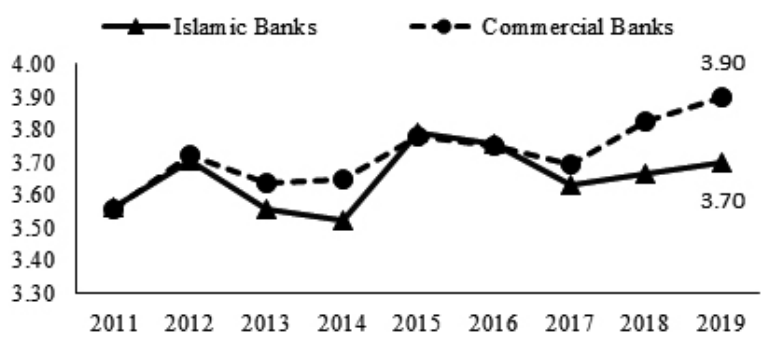

Fig. 3. Comparison of SNA reference rate between Islamic banks and commercial banks.

put of financial services provided by Islamic banking in the sense of profit-and-loss sharing on financing and deposits or called FISIM is calculated as follows:

$$
\begin{aligned}
\text { FISIM }= & \text { FISIM on Financing } \\
& + \text { FISIM on Deposits }
\end{aligned}
$$

Where: FISIM on Financing $=$ Stock of Financing $\times$ (Financing Rate - Reference Rate). FISIM on Deposits $=$ Stock of Deposits $\times$ (Reference Rate - Profit Rate).

Reference Rate is the midpoint between the financing and deposit rate which is less volatile. Hence, FISIM should be calculated according to the formula:

$$
\begin{aligned}
& \text { FISIM(Islamic Banking) } \\
= & \left(r_{\mathrm{L}}-\mathrm{rr}\right) \mathrm{y}_{\mathrm{L}}+\left(\mathrm{rr}-\mathrm{r}_{\mathrm{D}}\right) \mathrm{y}_{\mathrm{D}}
\end{aligned}
$$


a. Islamic Banks

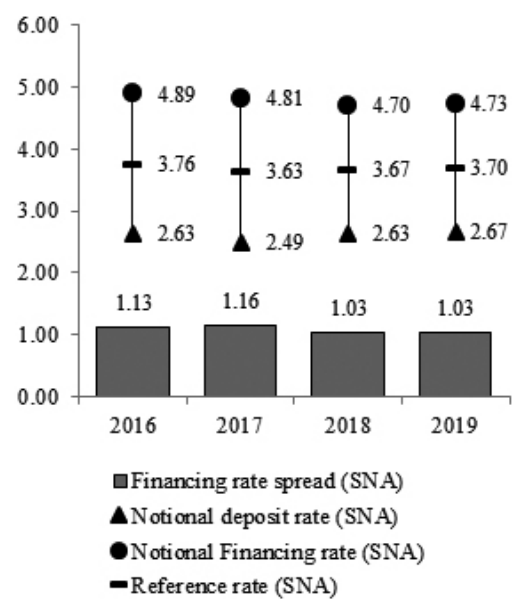

b. Commercial Banks

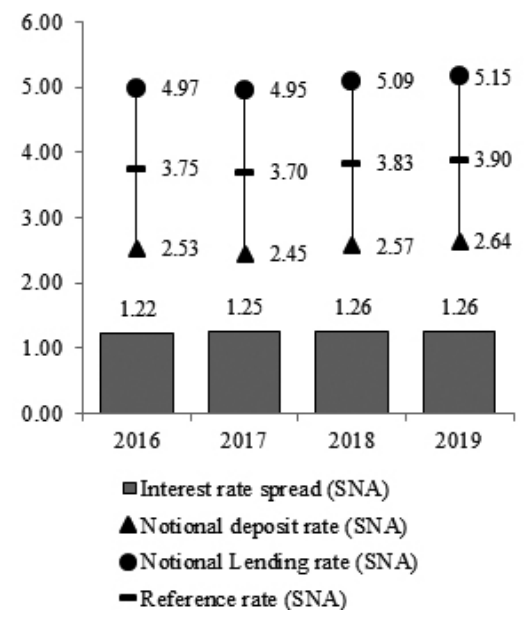

Fig. 4. Notional rate, reference rate and rate spread.

Whereby: $y_{L}-$ stock of financing. $y_{D}-$ stock of deposits. $\mathrm{rr}$ - reference rate. $\mathrm{r}_{\mathrm{L}}$ - rate of finance income received. $r_{D}$ - rate of profit distributed to depositors. $\left(\mathrm{r}_{\mathrm{L}}-\mathrm{rr}\right) @\left(\mathrm{r}_{\mathrm{D}}-\mathrm{rr}\right)$ - Bank rate spread@ margin rate.

By using the above formula, the process of calculating FISIM for Islamic banking are shown in Table 2.

There were two types of financial statements to look for data sources before the calculation process start. Firstly was Assets, Liabilities and Equities Statements, where data stock of financing and deposits located. Secondly was Income and Expenditure Statement, where data on income from finance and profit distributed to depositors should be situated. Both statements were needed to derive reference rate, notional financing rate, and notional deposits rate and ultimately derive a total number of FISIM. For comparison, Table 3 shows FISIM calculation for commercial banking.

Besides that, the import of FISIM already captured in Malaysia Balance of Payment compilation. Hence, the calculation of import FISIM has taken care of in the Balance of Payment System. Domestic FISIM then was allocated to users by using structure from the total of outstanding loan by sector (e.g., Agriculture, Manufacturing, Construction, etc.) and total deposit by the holder (e.g., Federal Government, businesses, individual etc.).

FISIM, in real terms, is calculated by deflated stocks of loans and deposits. At the moment, both conventional and Islamic banking uses the same type of deflator, ${ }^{2}$ and

\footnotetext{
${ }^{2}$ Each component to derived FISIM will have to deflate with the selected deflator as shown in the table below:
}

it was recommended among other National Statistical Offices (NSOs). In short, this article does not calculate FISIM in real terms.

\section{Findings}

The result shows that the SNA reference rate is showing a similar trend with BFR and BLR based on the above methodology. In general, BLR that use in commercial banks was lower than BFR use in Islamic banks. However, it was found that the SNA reference rate for Islamic banking was always lower than Commercial banking, except for the years 2015 and 2016 (Fig. 3). In 2015, Malaysia's GDP recorded a growth of 5.1\% and posted a slower rate of $4.4 \%$ in 2016 . The lower or higher SNA reference rate will be determined the higher or lower "margin", which was then translated as finance services. Malaysia uses a dual reference rate, which means FISIM for Islamic banking uses a finance reference rate while FISIM for commercial banking uses a lending reference rate.

The margin of finance services depends on finance or interest rate spread. The finance/lending rate spread was

\begin{tabular}{ccl}
\hline $\begin{array}{c}\text { Item } \\
1\end{array}$ & $\begin{array}{c}\text { Component } \\
\text { Loan and Deposits }\end{array}$ & \multicolumn{1}{c}{$\begin{array}{c}\text { Deflator } \\
\text { Consumer Price Index (CPI) } \\
\text { without fuel and food }\end{array}$} \\
2 & Interest received & $\begin{array}{l}\text { Base Lending Rate } \\
\text { Saving rate }\end{array}$ \\
3 & Interest expense & $\begin{array}{c}\text { Saving } \\
\text { Consumer Price Index (CPI) }\end{array}$
\end{tabular}

Consumer Price Index (CPI) should take out fuel and food item due to the high weighted in CPI basket and it will give the high impact to the constant prices if was included as deflator of FISIM. 


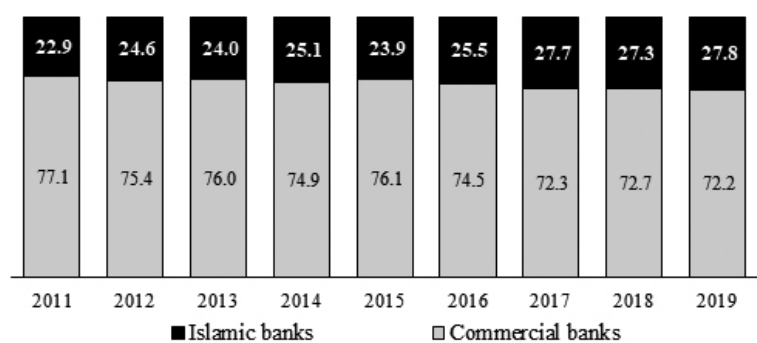

Fig. 5. Share of FISIM between Islamic banks and commercial banks.

the difference between the notional financing/lending rate and reference rate or reference rate and notional deposits rate. As we can see in Fig. 4, the reference rate was an average between notional financing/lending rate and notional deposits rate derived based on methodology, as shown in Tables 2 and 3. The notional rate, reference rate, and rate spread was the significant item or variable to determine the level of FISIM for each year.

The findings also show that the finance rate spread for Islamic banking was much smaller than commercial banks. However, in terms of share Islamic banks of FISIM, it was increasing from $22.9 \%$ (2011) to $27.8 \%$ in 2019 (Fig. 5) in tandem of double-digit growth recorded per annum for financing and deposits in Islamic banking.

\section{Conclusion}

The contribution of Islamic finance in Malaysia's economy is getting more significant, in line with the expansion and innovation in the Islamic financial services. With rapid development in Islamic banking and Islamic finance, DOSM continuously evaluating the methodology used in compiling the value-added of Islamic banking as well as Takaful and Islamic Capital Market. Malaysia manages to calculate Islamic finance by using conventional formula backed by Islamic concepts govern by the shariah advisory and committee. At least with this calculation, it serves well in the GDP compilation to avoid left out from the GDP compilation. The estimation supported by strong and consistent data. The Islamic finance compilation and estimation were not limited to the production account but beyond the other accounts (accumulation accounts, financial accounts, etc.). ${ }^{3}$

\footnotetext{
${ }^{3}$ The compilation beyond of production account will need comprehensive data sources especially for Islamic finance and will be a challenge on producing those statistics according to the national accounts framework.
}

In the absence of official guidelines on calculating Islamic finance output, the present method applied has served an adequate and acceptable way of estimating its contribution to the economy. Knowledge of Islamic terms (e.g., Qard, Mudarabah, Wakalah, etc.) in finance and insurance sector needs to be strengthened by making partner with the bank on the opportunity to attend Islamic conference, workshop, to build up capacity building and to keep update changes of Islamic finance/takaful in the community. It is recommended to encourage the setup of the Islamic finance framework. Hence, universal guidelines are needed to ensure the estimation of Islamic banking and finance in the national accounts is comparable among countries.

\section{Acknowledgments}

We would like to thank Ivo Havinga, Benson Sim Soon Seng and Herman Smith for excellent editorial assistance as well as reviewers for valuable comments on an earlier draft of the paper.

\section{References}

[1] Islamic Financial Services Industry Stability Report. Kuala Lumpur, Malaysia: Islamic Financial Services Board; 2019.

[2] Chong BS, Liu MH. Islamic banking: Interest-free or interestbased? Pacific Basin Financ J. 2009 Jan; 17(1): 125-44.

[3] Dar HA, Presley JR. Lack of profit loss sharing in islamic banking? Management and control imbalances. International Journal Islamic Financial Services. 2000; 2(0): 9-12.

[4] Bank Negara Malaysia. Significance G. White Box: Introduction of Islamic Variable Rate Mechanism White Box: The Framework of the Rate of Return White Box: Guidelines on the Specimen Reports and Financial Statements for Licensed Islamic Banks (GP8-i). 2003.

[5] EC, IMF, OECD, UN, World Bank. System of National Accounts. New York; 2009. 1-722. 